\title{
PREFORMULATION STUDIES OF PILOCARPINE HYDROCHLORIDE AS NIOSOMAL GELS FOR OCULAR DRUG DELIVERY
}

\author{
NEELAM JAIN ${ }^{1 *}$, ANURAG VERMA ${ }^{2}$ \\ ${ }^{1}$ Department of Pharmacy, Oriental College of Pharmacy and Research, Oriental University, Indore, Madhya Pradesh, India. ${ }^{2}$ Department of \\ Pharmacy, School of Pharmaceutical Sciences, IFTM University, Moradabad, Uttar Pradesh, India. Email: neelamnj02@gmail.com
}

Received: 13 April 2020, Revised and Accepted: 16 April 2020

\section{ABSTRACT}

Objective: Pilocarpine hydrochloride is a direct acting cholinergic parasympathomimetic agent which directly stimulates cholinergic receptor $\left(\mathrm{M}_{3}\right)$. It is a drug used in the treatment of chronic open-angle glaucoma for over 100 years. Designing a new ophthalmic dosage form for pilocarpine hydrochloride compels performing preformulation studies for drug. Therefore, the current aim of the study was to investigate some of the important physicochemical properties of pilocarpine hydrochloride which can help to select subsequent approaches during the development of niosomal gel for ocular use.

Methods: Preformulation studies of drug were carried out for identification (physical appearance, melting point, and UV spectrophotometric analysis), solubility profile, lipophilicity (partition coefficient), compatibility studies by Fourier-transform infrared (FTIR) spectroscopy, and thermal behavior by differential scanning calorimetry (DSC).

Results: The melting point of pilocarpine hydrochloride was found to be $204 \pm 3^{\circ} \mathrm{C}$. The $\log \mathrm{P}$ value was found to be $1.12 \pm 0.02$, from which it can be interpreted that drug is highly hydrophilic in nature. The scanned $\lambda_{\max }$ was found to be $215 \mathrm{~nm}$. No significant changes were found when FTIR spectra of physical mixture compared with FTIR spectra of pure drug and excipients. This indicates absence of any possible interaction between the drug and excipients which confirms the identity and purity of drug. DSC thermogram of pure drug showed a sharp exothermic peak at $191.923^{\circ} \mathrm{C}$ (area $=68.890 \mathrm{~mJ}$, delta $\mathrm{H}=22.963 \mathrm{~J} / \mathrm{g}$ ), indicating the crystal melting point of the drug.

Conclusion: These results suggest that the pilocarpine hydrochloride serves as suitable candidate for ocular drug delivery system.

Keywords: Pilocarpine hydrochloride, Preformulation, Ocular delivery, Spectrometric analysis, Compatibility

(C) 2020 The Authors. Published by Innovare Academic Sciences Pvt Ltd. This is an open access article under the CC BY license (http://creativecommons. org/licenses/by/4. 0/) DOI: http://dx.doi.org/10.22159/ajpcr.2020.v13i6.37523

\section{INTRODUCTION}

Preformulation study is an important tool for the determination of physical and chemical properties of the drug before the development of dosage form. The nature of the drug highly affects the processing parameters such as method of preparation, entrapment efficiency, compatibility, and pharmacokinetic response of the formulation. Preformulation studies are indispensable protocol for the development of safe, effective, and stable dosage form. Thus, to ensure optimum condition for clinically beneficial delivery system, preformulation studies were carried out. A thorough understanding of these properties ultimately provides a rational for formulation design. Characterization of drug and drug-excipient compatibility studies was done in this phase to provide a useful support in the development of dosage form [1]

Pilocarpine hydrochloride is a drug used in the treatment of chronic open-angle glaucoma for over 100 years [2]. It is a parasympathomimetic alkaloid obtained from the leaves of tropical South American shrubs from the genus Pilocarpus [3]. It is a non-selective muscarinic receptor agonist which acts therapeutically at the muscarinic acetylcholine receptor $\mathrm{M}_{3}$, found on the iris sphincter muscle, causing the muscle to contract resulting in pupil constriction (miosis). Pilocarpine hydrochloride also acts on the ciliary muscle and causes it to contract. When the ciliary muscle contracts, it opens the trabecular meshwork through increased tension on the scleral spur. This action facilitates the rate that aqueous humor leaves the eye to decrease in intraocular pressure, which ultimately helpful in treating open-angle glaucoma [4].

The major drawbacks associated with pilocarpine $\mathrm{HCl}$, administered as an eye drop, were its low ocular bioavailability (1-3\%) and short precorneal residence time. Niosomes, administered as an ophthalmic gel, containing bioadhesive polymer (locust bean gum and Carbopol 934), are capable of localizing and maintaining drug activity at its site of action with prolonged precorneal residence time and improved bioavailability [6].

Therefore, the current aim of the study was to investigate some of the important physicochemical properties of pilocarpine $\mathrm{HCl}$ which can help to select subsequent approaches during the development of niosomal gel for ocular use.

Preformulation studies were carried out for identification (physical appearance, melting point, and UV spectrophotometric analysis), solubility profile, lipophilicity (n-octanol-water partition-coefficient determination), spectrometric fingerprints, and compatibility studies by Fourier transform infrared (FTIR) and thermal behavior analysis by DSC. The use of preformulation parameter maximizes the chances of getting a formulation which is safe, efficacious, and stable product and at the same time provides optimization of the drug product quality [7].

\section{Characterization of pilocarpine $\mathbf{H C l}$}

Organoleptic properties

Organoleptic properties of the pilocarpine $\mathrm{HCl}$ were characterized on the basis of appearance, color, odor, and taste by visual inspection.

\section{Melting point determination}

The melting point of a drug was determined using digital melting point apparatus (DB- 31354, Decibels Instruments, Perfit, India). In this method, a tiny amount of drug was introduced into a small capillary tube, attaching this to the stem of a thermometer centered in a heating bath, heating the bath slowly, and observing the temperatures at 
which melting of drug begins and is completed. The melting point was recorded and compared with literature value.

\section{Determination of solubility}

Qualitative solubility

Qualitative solubility of pilocarpine $\mathrm{HCl}$ in different solvents was determined according to USP NF, 2007 [8]. Pilocarpine $\mathrm{HCl}$ (1 mg) was accurately weighed and transferred into a $10 \mathrm{ml}$ test tube; then, it was dissolved in the respective solvents $(1 \mathrm{ml}$ each) such as distilled water, phosphate buffer saline ( $\mathrm{pH}$ 7.4), methanol, ethanol, acetic acid, acetic anhydride, and diethyl ether. The solubility $(\mathrm{mg} / \mathrm{ml})$ was observed by visual inspection and compared with that available in literature.

\section{Quantitative solubility}

Quantitative solubility analysis of drug was done by taking $5 \mathrm{ml}$ of each solvent and drug in gm(s) into the solvent till saturation of solvent. Solutions were filtered and absorbance was recorded using UV spectrophotometer and the concentration of drug dissolved in respective solvents was calculated [9]. Different solvents such as distilled water, phosphate buffer saline $(\mathrm{pH}$ 7.4), and simulated tear fluid $\mathrm{pH} 7.4$ were used for the solubility determination. This is done to determine the capacity of the solvent for dissolving the drug in it.

\section{Lipophilicity (partition coefficient)}

The partition coefficient of a chemical compound provides a thermodynamic measure of its hydrophilicity-lipophilicity balance. The partition coefficient of a substance between n-octanol and water is referred to as $\log \mathrm{P}_{\mathrm{o} / \mathrm{w}^{\prime}}$, which corresponds to the negative logarithm of the ratio of the concentration of the substance in the aqueous and hydrophobic phases [10]. The partition coefficient of pilocarpine $\mathrm{HCl}$ was carried out in water: octanol (1:1) using shake flask procedure.

\section{METHODS}

Before a partition coefficient is determined, the phases of the solvent system were mutually saturated by shaking at the temperature of the experiment. To do this, high purity analytical grade n-octanol and water were taken into a separating funnel in 1:1 ratio. Then, separating funnel was shaken for $30 \mathrm{~min}$ to allow complete mixing and then the funnel was allowed to stand for $24 \mathrm{~h}$ to develop two phases which were saturated with each other after that the drug in minimum quantity (not more than $0.01 \mathrm{~mol} / \mathrm{liter}$ ) was added to one of the phase and the funnel was again shaken for $30 \mathrm{~min}$ and then allow to stand for $1 \mathrm{~h}$ after that the amount of drug in both phases (n-octanol and water) was determined spectrophotometrically.

The partition coefficient is a ratio of concentrations of unionized compound between the two solutions. To measure the partition coefficient of ionizable solutes, the $\mathrm{pH}$ of the aqueous phase is adjusted such that the predominant form of the compound is unionized. The logarithm of the ratio of the concentrations of unionized solute in the solvents is called $\log \mathrm{P}[11,12]$.

$$
\log P_{\text {oct/wat }}=\log \left(\frac{[\text { solute }]_{\text {octanol }}}{[\text { solute }]_{\text {wation }}^{\text {unized }}}\right)
$$

\section{UV-visible spectrophotometric analysis}

Determination of $\lambda_{\max }$ of pilocarpine $\mathrm{HCl}$ in phosphate buffer solution (PBS) ( $p H$ 7.4)

A standard stock solution of pilocarpine $\mathrm{HCl}$ was prepared by dissolving $100 \mathrm{mg}$ of drug in a $100 \mathrm{ml}$ volumetric flask and the volume was made up to $100 \mathrm{ml}$ using PBS of $\mathrm{pH} 7.4$ to get the concentration of $1000 \mu \mathrm{g} / \mathrm{ml}$ of standard pilocarpine $\mathrm{HCl}$. From the standard stock solution, $10 \mathrm{ml}$ was pipette out into $100 \mathrm{ml}$ volumetric flask and the volume was made up to $100 \mathrm{ml}$ with PBS of pH 7.4 to get the concentration of $100 \mu \mathrm{g} / \mathrm{ml}$. From this solution, $1 \mathrm{ml}$ was pipette out into $10 \mathrm{ml}$ volumetric flask and the volume was made up to $10 \mathrm{ml}$ with $\mathrm{PBS}$ of $\mathrm{pH} 7.4$ to get the concentration of $10 \mu \mathrm{g} / \mathrm{ml}$. Maximum wavelength $\left(\lambda_{\text {max }}\right)$ was obtained by scanning the resulting solution $(14 \mu \mathrm{g} / \mathrm{ml})$ in the wavelength region between $200 \mathrm{~nm}$ and $400 \mathrm{~nm}$ using UV-visible spectrophotometer (UV1700 PharmaSpec, Shimadzu, Japan).

Preparation of standard curve of pilocarpine $\mathrm{HCl}$ in PBS of pH 7.4 From the above prepared stock solution, five dilutions were made using PBS of pH 7.4 which has ultimate concentration $12 \mu \mathrm{g} / \mathrm{ml}, 14 \mu \mathrm{g} / \mathrm{ml}$, $16 \mu \mathrm{g} / \mathrm{ml}, 18 \mu \mathrm{g} / \mathrm{ml}$, and $20 \mu \mathrm{g} / \mathrm{ml}$. Then, check the $\mathrm{pH}$ of the diluted solutions to confirm that the diluted solutions were ranges in the $\mathrm{pH}$ of 7.4. The absorbance was measured at $\lambda_{\text {ma }} \times 215 \mathrm{~nm}$ using UV-visible spectrophotometer.

\section{FTIR spectroscopy}

FTIR spectra of the pure drug were obtained using FTIR spectrometer (FTIR-8400S spectrophotometer, Shimadzu, Japan). Sample was ground thoroughly with $\mathrm{KBr}$ powder in mortar and pestle, in a weight ratio of 1:100 and then pressed the mixture in dies set in pellet press under a hydraulic pressure of 15 tons for a minute. Release the pressure by rotating the side valve in anticlockwise direction to take of the pellet from the dies set. Then, the pellet was placed in the sample holder and spectral scanning was taken in the wavelength region between 4000 and $400 \mathrm{~cm}^{-1}$ at a resolution of $4 \mathrm{~cm}^{-1}$ and scan speed of $2 \mathrm{~mm} / \mathrm{s}$ [13].

\section{Drug excipient compatibility screening by FTIR}

FTIR spectra of locust bean gum, Carbopol 934, and a physical mixture of locust bean gum: Carbopol 934:pilocarpine $\mathrm{HCl}$ in a weight ratio of 1:1:1 were obtained using FTIR spectrometer (FTIR-8400S spectrophotometer, Shimadzu, Japan). Each sample was ground thoroughly with $\mathrm{KBr}$ powder in a weight ratio of 1:100 and then pellets were prepared using a hydraulic pellet press under a hydraulic pressure of 15 tons for a minute. Then, the pellet was placed in the sample holder and spectral scanning was taken in the wavelength region between 4000 and $400 \mathrm{~cm}^{-1}$ at a resolution of $4 \mathrm{~cm}^{-1}$ and scan speed of $2 \mathrm{~mm} / \mathrm{s}$. IR spectra of the physical mixture were then compared with the IR spectra of pure drug and polymer to find out the evidence of any compatibility [14]. Fig. 8.

\section{Differential scanning calorimetry (DSC)}

DSC analysis was performed on the pure drug using PerkinElmer instrument (Pyris-1, Osaka, Japan), available at the Department of Textile Technology, Indian Institute of Technology, New Delhi, India. Initially, the moisture was removed by heating the samples, and then, each sample (about 3-7 mg) was accurately weighed into platinum crucible $40 \mu \mathrm{l}$ aluminum pan in hermetically sealed condition, where alpha alumina powder used as a reference. Thermograms were recorded from $50^{\circ} \mathrm{C}$ to $300^{\circ} \mathrm{C}$ at the heating rate of $20^{\circ} \mathrm{C} / \mathrm{min}$ under a constant flow of an inert nitrogen gas atmosphere with the flow rate of $20 \mathrm{ml} / \mathrm{min}$ [15]. The DSC spectra used to find out the exotherm peak position or any change in their position compared with the standard spectra.

\section{RESULTS AND DISCUSSION}

\section{Characterization of drug}

Organoleptic properties

Organoleptic properties of the drug sample were found to be as given in Table 1. The physical properties were found as similar as reported in literature that proves the identity of drug.

\section{Melting point determination}

The melting point of drug was determined in triplicate and their mean values with standard deviation are shown in Table 2 . The melting point of pilocarpine $\mathrm{HCl}$ was found to be $204 \pm 3^{\circ} \mathrm{C}$, which corresponds to the literature value of $204-205^{\circ} \mathrm{C}$ that proves the identity and purity of drug.

Table 1: Organoleptic properties of pilocarpine $\mathrm{HCl}$

\begin{tabular}{ll}
\hline Organoleptic properties & Results \\
\hline Physical form & Slightly hygroscopic crystalline powder \\
Color & White to off-white \\
Odor & Odorless \\
Taste & Tasteless \\
\hline
\end{tabular}


Determination of solubility

\section{Qualitative solubility}

The qualitative solubility data of pilocarpine $\mathrm{HCl}$ in different solvents at room temperature are shown in Table 3.

\section{Qualitative solubility}

Results of quantitative solubility data of the drug in different solvents at room temperature are given in Table 4.

These results indicated that the available pilocarpine $\mathrm{HCl}$ form is freely soluble in water and there is no noticeable difference between the solubility of the pilocarpine $\mathrm{HCl}$ form used and the solubility of the reference pilocarpine $\mathrm{HCl}$.

\section{Partition coefficient}

The $\log \mathrm{P}$ value of drug was determined in triplicate and their mean values with standard deviation are shown in Table 5 . The log $P$ value was found to be $1.12 \pm 0.02$ and reported value was 1.15 from which it can be interpreted that drug is highly hydrophilic in nature. Hence, the

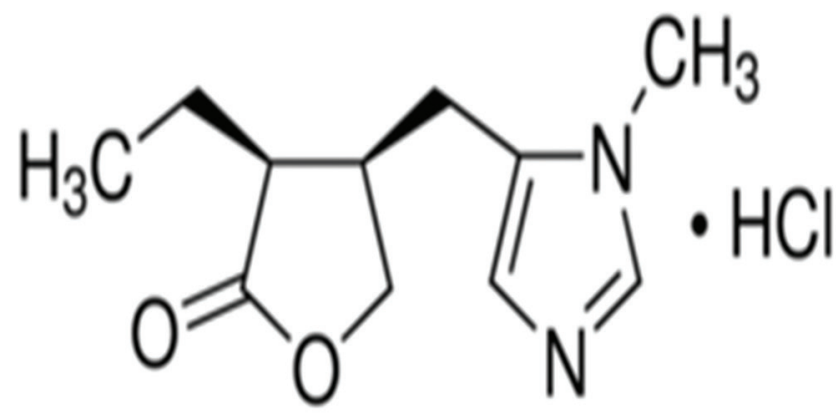

Fig. 1: Chemical structure of pilocarpine $\mathrm{HCl}$ [5]

Table 2: Melting point of pilocarpine $\mathrm{HCl}$

\begin{tabular}{lll}
\hline S. No. & Melting point $\left({ }^{\circ} \mathbf{C}\right)$ & Mean \pm S.D. $\left({ }^{\circ} \mathbf{C}\right)$ \\
\hline 1. & 205 & $204 \pm 3^{\circ} \mathrm{C}$ \\
2. & 203 & \\
3. & 204 & \\
\hline
\end{tabular}

Table 3: Qualitative solubility of drug in different solvents at $37^{\circ} \mathrm{C}$

\begin{tabular}{lll}
\hline S. No. & Solvent $(\mathbf{1} \mathbf{~ m l})$ & Solubility of the drug (1 $\mathbf{~ m g})$ \\
\hline 1. & Distilled water & Freely soluble \\
2. & Phosphate buffer saline pH 7.4 & Freely soluble \\
3. & Methanol & Freely soluble \\
4. & Ethanol & Freely soluble \\
5. & Acetic acid & Freely soluble \\
6. & Acetic anhydride & Sparingly soluble \\
7. & Diethyl ether & Insoluble \\
\hline
\end{tabular}

Table 4: Quantitative solubility of drug in different solvents at $37^{\circ} \mathrm{C}$

\begin{tabular}{lll}
\hline S. No. & Solvent & Concentration of drug in solvent $(\mathbf{m g} / \mathbf{m l})$ \\
\hline 1. & Distilled water & 2.02 \\
2. & PBS pH 7.4 & 2.13 \\
\hline
\end{tabular}

Table 5: Partition coefficient of pilocarpine $\mathrm{HCl}$

\begin{tabular}{lll}
\hline S. No. & Log $\mathbf{p}$-value & Mean \pm SD \\
\hline 1. & 1.12 & $1.12 \pm 0.02$ \\
2. & 1.13 & \\
3. & 1.11 & \\
\hline
\end{tabular}

corneal epithelium is expected to be the rate-limiting barrier for ocular absorption [16]. This is an incentive to consider niosomes (surfactant/ lipid-based system) for the ocular delivery of pilocarpine $\mathrm{HCl}$.

\section{Standard curve of pilocarpine $\mathbf{H C l}$}

Determination of $\lambda_{\text {max }}$ of pilocarpine $\mathrm{HCl}$ in $\mathrm{PBS}$ ( $\mathrm{pH} 7.4$ )

UV spectrophotometric study was carried out to determine the $\lambda_{\text {max }}$ of pilocarpine $\mathrm{HCl}$ in $\mathrm{PBS}$ of $\mathrm{pH}$ 7.4. $\lambda_{\max }$ of pilocarpine $\mathrm{HCl}$ was found to be $215 \mathrm{~nm}$, as shown in Table 6. Fig. 2 shows the peak at $215 \mathrm{~nm}$ of pilocarpine $\mathrm{HCl}$ in PBS of $\mathrm{pH}$ 7.4. The scanned $\lambda_{\max }$ was found to be similar as that of reported $\lambda_{\text {max }}(215 \mathrm{~nm})$.

Preparation of standard curve of pilocarpine $\mathrm{HCl}$ in $\mathrm{PBS}$ of $\mathbf{p H ~} 7.4$ The concentration and absorbance data of pilocarpine $\mathrm{HCl}$ in $\mathrm{PBS}$ of pH 7.4 are given in Table 7. This absorbance was plotted on Y-axis against concentration on $\mathrm{X}$-axis and slope of the standard curve was obtained that is shown in Fig. 3. The slope and intercept were found to be 0.0213 and 0.0016 , respectively, as shown in Fig. 4.

\section{FTIR spectroscopy}

FTIR spectra of the pure drug were obtained using FTIR spectrometer (FTIR-8400S spectrophotometer, Shimadzu, Japan) and are presented in Fig. 5. The interpretation of FTIR spectra of pilocarpine $\mathrm{HCl}$ is shown in Table 8. Pilocarpine $\mathrm{HCl}$ showed the principle IR peaks at $3217.10 \mathrm{~cm}^{-\mathrm{m}}$ resulted from N-H stretching, the peak at $1764.75 \mathrm{~cm}^{-\mathrm{m}}$ resulted from $\mathrm{C}=0$ stretching, the peak at $1612.38 \mathrm{~cm}^{-\mathrm{c}}$ resulted from $\mathrm{C}=\mathrm{N}$ stretching, the peak at $1552.59 \mathrm{~cm}^{-\mathrm{m}}$ resulted from $\mathrm{N}=\mathrm{H}$ bending, and the peak around $3400.27 \mathrm{~cm}^{-\mathrm{a}}$, indicating stretching of hydroxyl group. All the principal peaks of pilocarpine $\mathrm{HCl}$ are present in the spectra, which confirm the purity and identity of drug.

Drug-excipient compatibility screening by FTIR

FTIR spectra of locust bean gum, Carbopol 934, and a physical mixture of locust bean gum: Carbopol 934:pilocarpine $\mathrm{HCl}$ in a weight

Table 6: Scanned $\lambda \max$ and absorbance of pilocarpine $\mathrm{HCl}$ in PBS (pH 7.4)

\begin{tabular}{llll}
\hline S. No. & Strength $(\boldsymbol{\mu g} / \mathbf{m l})$ & Scanned $\boldsymbol{\lambda}_{\max }(\mathbf{n m})$ & Absorbance \\
\hline 1. & 14 & 215 & 0.313 \\
2. & 14 & 215 & 0.180 \\
3. & 14 & 215 & 0.076 \\
\hline
\end{tabular}

Table 7: Standard curve data of pilocarpine $\mathrm{HCl}$ in $\mathrm{PBS}$ pH 7.4

\begin{tabular}{lll}
\hline S. No. & Concentration $(\boldsymbol{\mu g} / \mathbf{m l})$ & Absorbance \\
\hline 1. & 0 & 0.000 \\
2. & 12 & 0.252 \\
3. & 14 & 0.294 \\
4. & 16 & 0.344 \\
5. & 18 & 0.373 \\
6. & 20 & 0.432 \\
\hline
\end{tabular}

Table 8: Interpretation of FTIR spectra of pilocarpine $\mathrm{HCl}$

\begin{tabular}{|c|c|c|c|}
\hline S. No. & Functional group & $\begin{array}{l}\text { Reported } \\
\text { frequency }\left(\mathrm{cm}^{-1}\right)\end{array}$ & $\begin{array}{l}\text { Observed } \\
\text { frequency }\left(\mathrm{cm}^{-1}\right)\end{array}$ \\
\hline 1. & N-H stretching & $3400-3250$ & 3217.10 \\
\hline 2. & $\mathrm{C}=\mathrm{O}$ stretching & $1900-1600$ & 1764.75 \\
\hline 3. & $\mathrm{C}=\mathrm{N}$ stretching & $1700-1600$ & 1612.38 \\
\hline 4. & $\mathrm{~N}=\mathrm{H}$ bending & $1700-1500$ & 1552.59 \\
\hline 5. & $\mathrm{C}-\mathrm{H}$ bend in plane & $1500-1300$ & 1483.16 \\
\hline 6. & C-C stretching & $1200-800$ & 1180.35 \\
\hline 7. & $\mathrm{~N}-\mathrm{H}$ rocking & $900-700$ & 759.90 \\
\hline 8. & $\mathrm{C}-\mathrm{Cl}$ stretching & $800-600$ & 626.82 \\
\hline 9. & $\begin{array}{l}\text { O-H stretching, } \\
\text { H-bonded }\end{array}$ & $3500-3200$ & 3400.27 \\
\hline
\end{tabular}


ratio of 1:1:1 were obtained using FTIR spectrometer (FTIR-8400S spectrophotometer, Shimadzu, Japan) and are presented in Figs. 6 and 7, respectively, and the interpretation of FTIR spectra is shown in Table 9-11, respectively.

No significant changes were found when FTIR spectra of physical mixture compared with FTIR spectra of pure drug and excipients. This

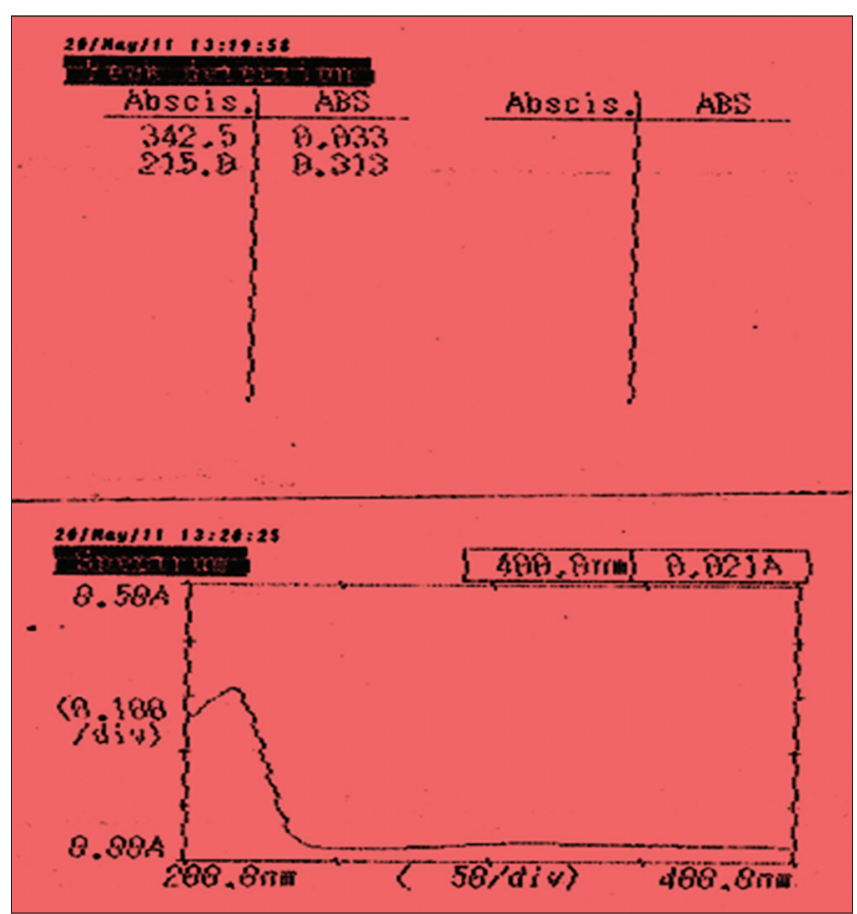

Fig. 2: Peak of pilocarpine $\mathrm{HCl}$ in phosphate buffer solution of pH 7.4

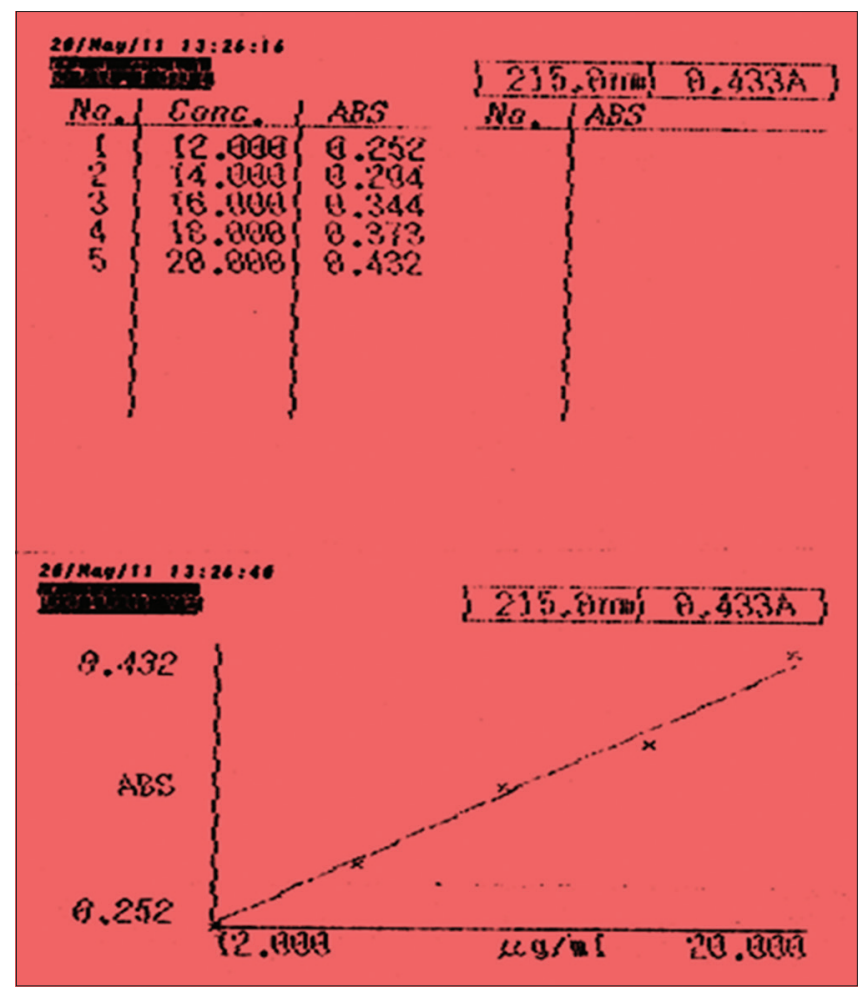

Fig. 3: Standard curve of pilocarpine $\mathrm{HCl}$ showing in PBS pH 7.4 indicates the absence of any possible interaction between the drug and excipients.

\section{Differential scanning calorimetric (DSC)}

DSC thermogram tracings of pilocarpine $\mathrm{HCl}$ are shown in Fig. 9. It showed a sharp exothermic peak at $191.923^{\circ} \mathrm{C}$ (area $=68.890 \mathrm{~mJ}$, delta $\mathrm{H}=22.963 \mathrm{~J} / \mathrm{g}$ ), indicating the crystal melting point of the drug. This result is in contrary to that of the reference melting point of pilocarpine $\mathrm{HCl}$ which is $204-205^{\circ} \mathrm{C}$. The marked difference between the observed melting point and the reference one is attributed to crystallization form of the drug.

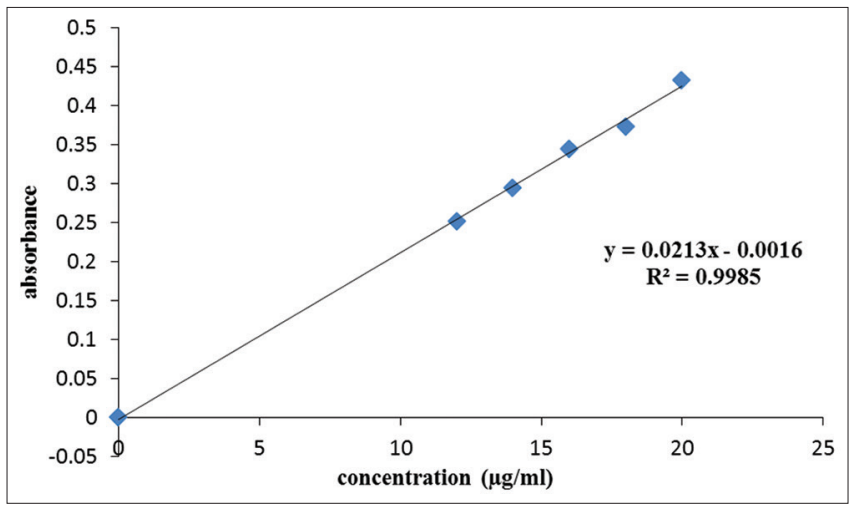

Fig. 4: Standard curve of pilocarpine $\mathrm{HCl}$ in PBS pH 7.4

Table 9: Interpretation of Fourier transform infrared spectra of locust bean gum

\begin{tabular}{|c|c|c|c|}
\hline S. No. & Functional group & $\begin{array}{l}\text { Reported } \\
\text { frequency } \\
\left(\mathrm{cm}^{-1}\right)\end{array}$ & $\begin{array}{l}\text { Observed } \\
\text { frequency } \\
\left(\mathrm{cm}^{-1}\right)\end{array}$ \\
\hline 1. & O-H stretching, H-bonded & $3500-3200$ & 3458.13 \\
\hline 2. & $\mathrm{C}-\mathrm{O}-\mathrm{C}$ stretching in ring & $1150-1000$ & 1056.92 \\
\hline 3. & $\mathrm{C}-\mathrm{H}$ stretching in ring & $3330-3000$ & 3272.98 \\
\hline 4. & C-H stretching & $3000-2840$ & 2923.88 \\
\hline 5. & C-H bending & $1470-1450$ & 1440.73 \\
\hline
\end{tabular}

Table 10: Interpretation of Fourier transform infrared spectra of Carbopol 934

\begin{tabular}{|c|c|c|c|}
\hline S. No. & Functional group & $\begin{array}{l}\text { Reported } \\
\text { frequency }\left(\mathrm{cm}^{-1}\right)\end{array}$ & $\begin{array}{l}\text { Observed } \\
\text { frequency }\left(\mathrm{cm}^{-1}\right)\end{array}$ \\
\hline 1. & O-H stretching & $3640-3610$ & 3640.07 \\
\hline 2. & C-C stretching & $1300-800$ & 1240.14 \\
\hline 3. & C-H stretching & $3000-2840$ & 2894.95 \\
\hline 4. & $\mathrm{C}=\mathrm{O}$ stretching & $1725-1700$ & 1716.53 \\
\hline
\end{tabular}

Table 11: Interpretation of Fourier transform infrared spectra of physical mixture

\begin{tabular}{|c|c|c|c|}
\hline S. No. & Functional group & $\begin{array}{l}\text { Reported } \\
\text { frequency } \\
\left(\mathrm{cm}^{-1}\right)\end{array}$ & $\begin{array}{l}\text { Observed } \\
\text { frequency } \\
\left(\mathrm{cm}^{-1}\right)\end{array}$ \\
\hline 1. & N-H stretching & $3400-3250$ & 3217.10 \\
\hline 2. & $\mathrm{~N}-\mathrm{H}$ bending & $1650-1580$ & 1540.13 \\
\hline 3. & $\mathrm{~N}-\mathrm{H}$ wagging & $910-665$ & 632.26 \\
\hline 4. & $\mathrm{C}=\mathrm{N}$ stretching & $1700-1600$ & 1677.95 \\
\hline 5. & C-H stretching & $3000-2850$ & 2937.38 \\
\hline 6. & $\mathrm{C}-\mathrm{H}$ bending & $1470-1450$ & 1427.23 \\
\hline 7. & Aromatic $\mathrm{C}=\mathrm{C}$ stretching & $1675-1650$ & 1637.45 \\
\hline 8. & O-H stretching, H-bonded & $3500-3200$ & 3400.27 \\
\hline 9. & $\mathrm{C}-\mathrm{O}-\mathrm{C}$ stretching in ring & $1150-1000$ & 1116.71 \\
\hline
\end{tabular}




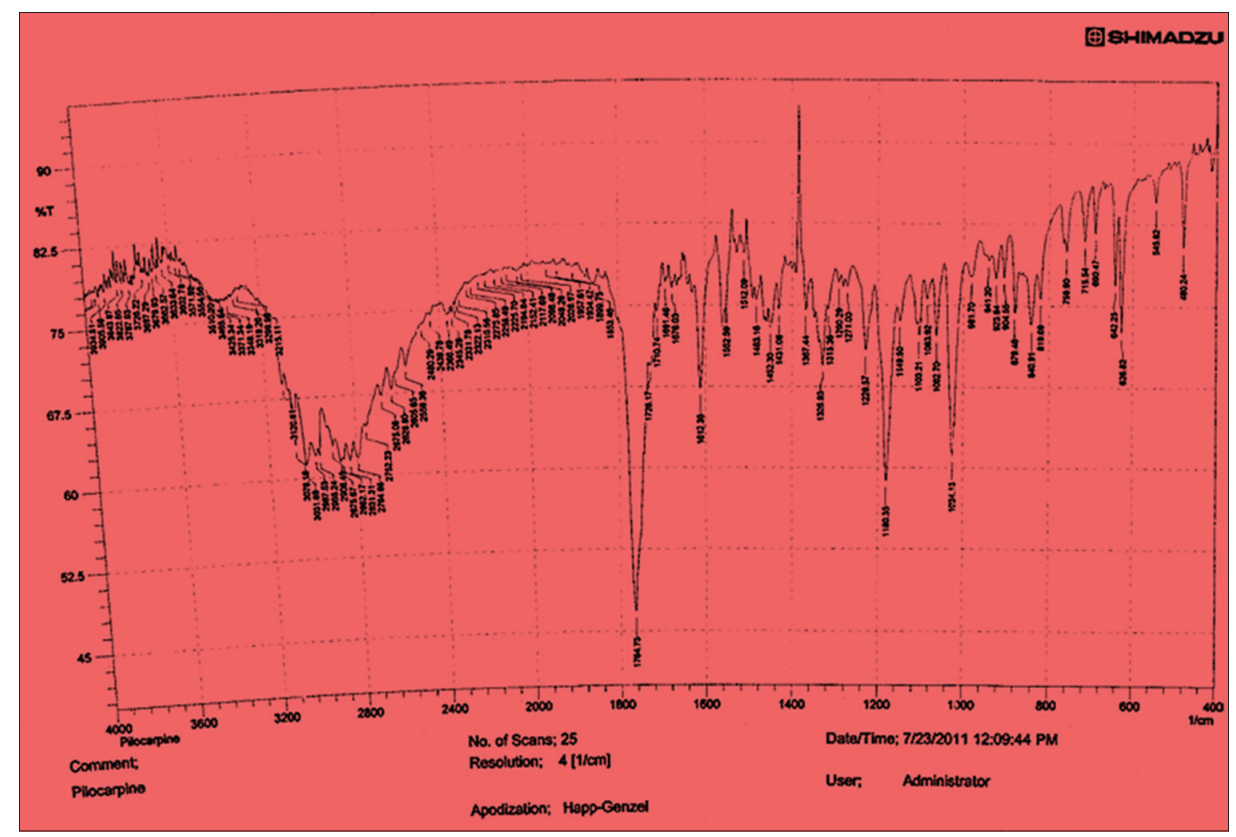

Fig. 5: Fourier transform infrared spectra of pilocarpine $\mathrm{HCl}$

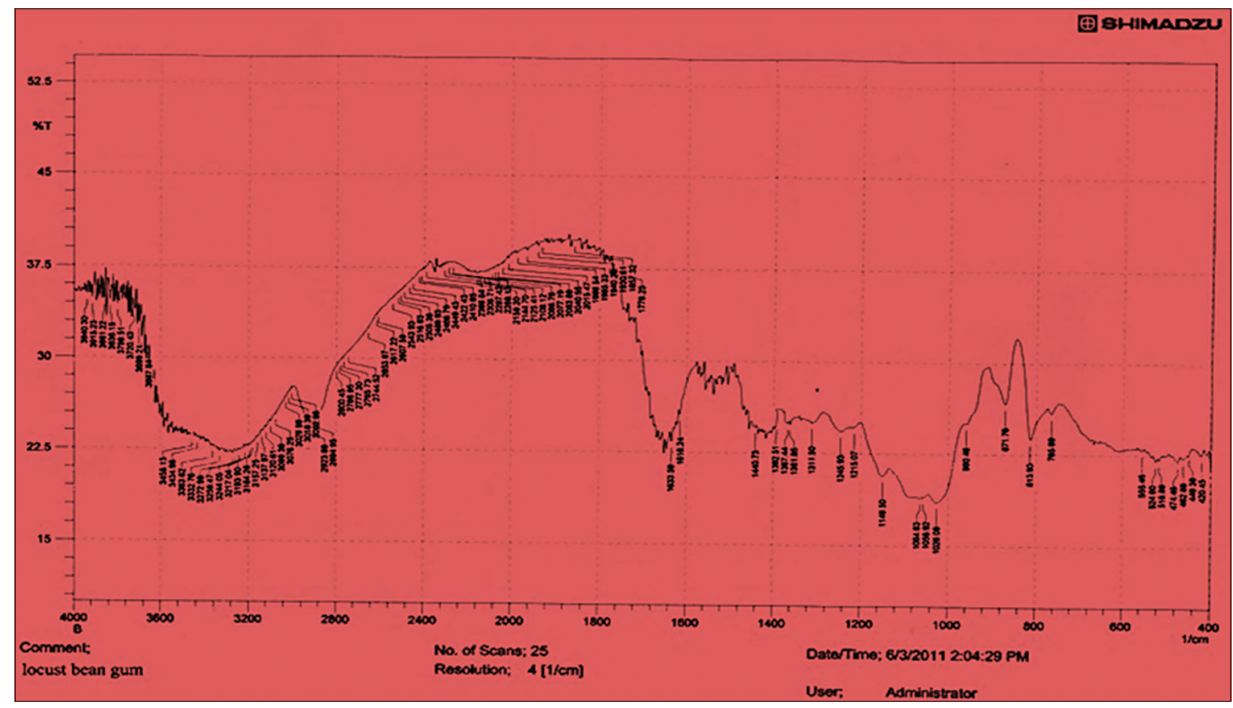

Fig. 6: Fourier transform infrared spectra of locust bean gum

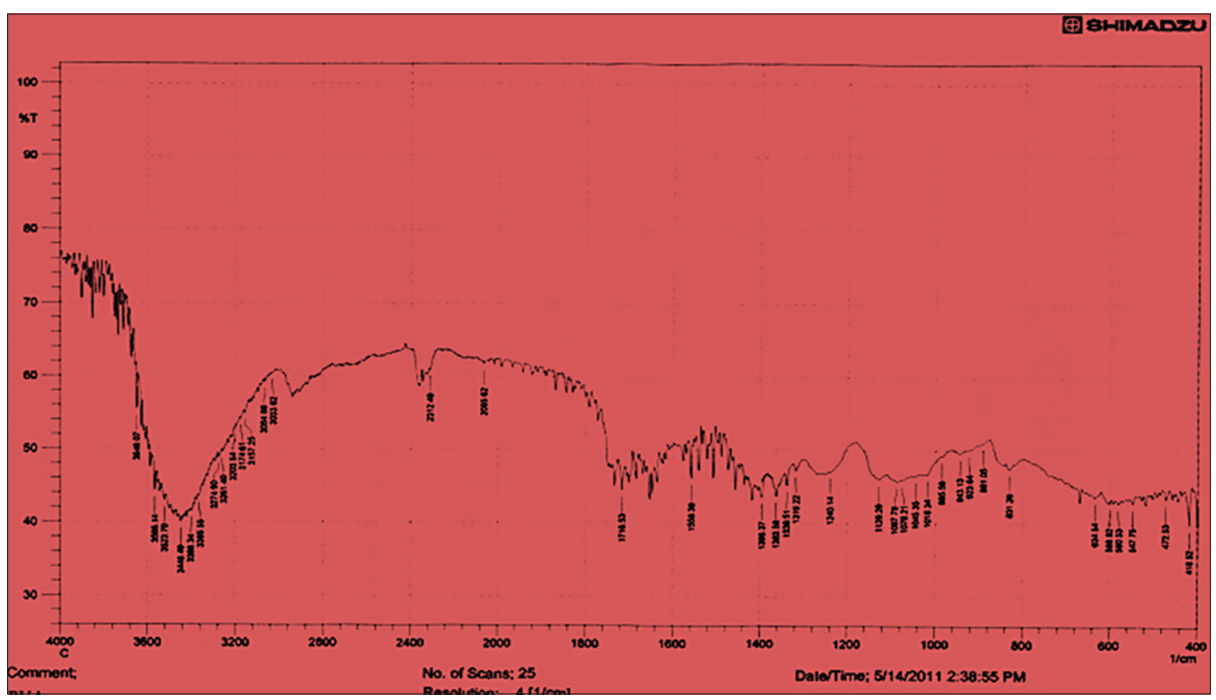

Fig. 7: Fourier transform infrared spectra of Carbopol 934 


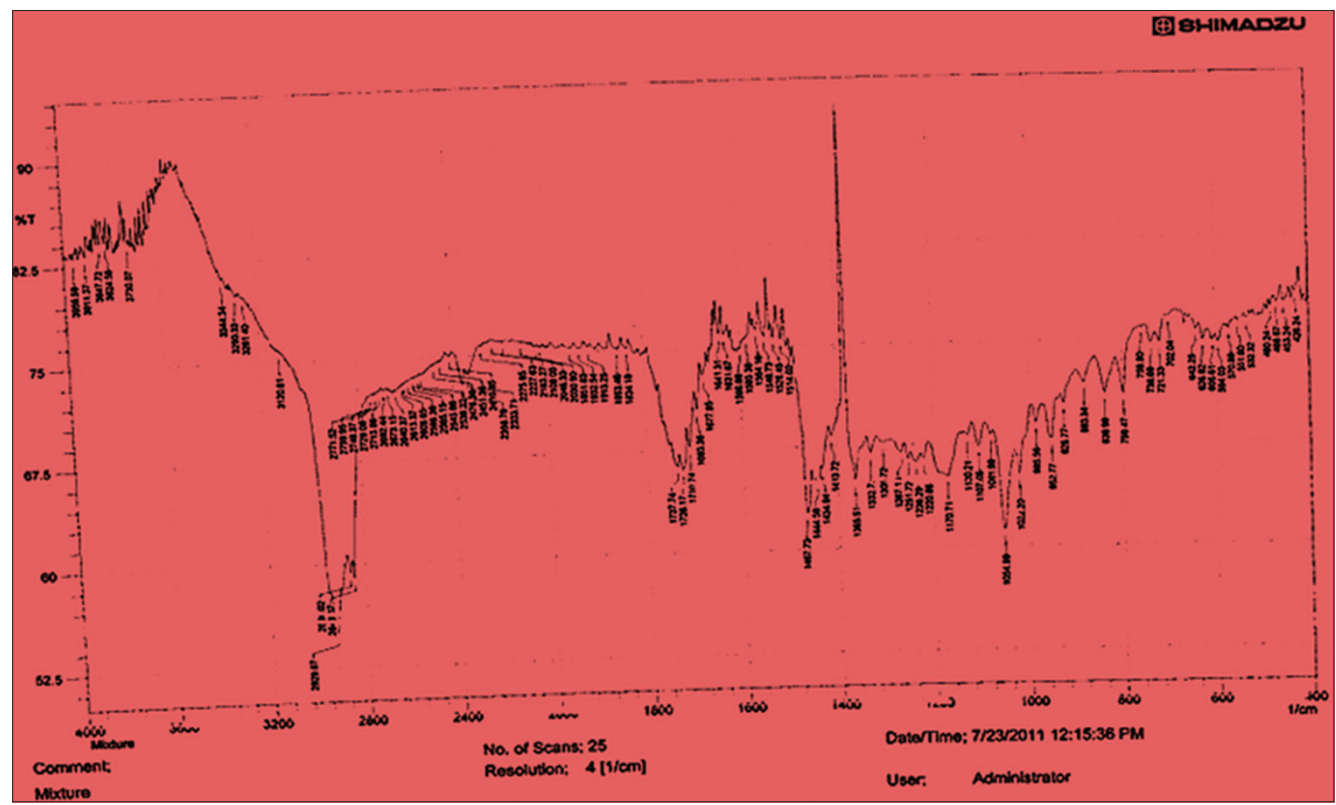

Fig. 8: Fourier transform infrared spectra of physical mixture

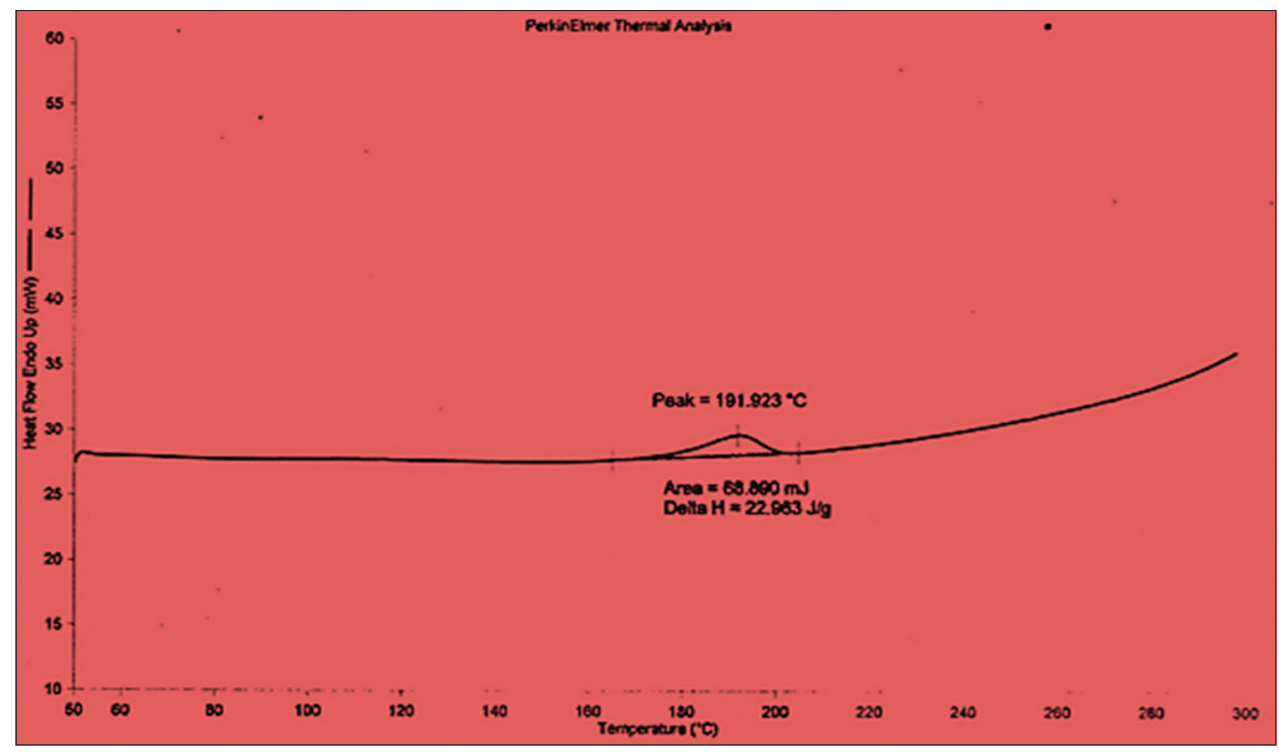

Fig. 9: DSC thermogram tracings of pilocarpine $\mathrm{HCl}$

\section{CONCLUSION}

The preformulation parameter such as melting point and UV spectrophotometric analysis, solubility profile, partition coefficient, spectrometric fingerprints, and compatibility studies by FTIR and thermal behavior analysis by DSC maximizes the chances of getting a formulation which is safe, efficacious, and stable product and at the same time provides optimization of the drug product quality. On the basis of these studies, it was concluded that the pilocarpine $\mathrm{HCl}$ serves as suitable candidate for niosomal gel for ocular use.

\section{ACKNOWLEDGMENTS}

The authors are thankful to the directors of Oriental College of Pharmacy and Research, Oriental University and School of Pharmaceutical Sciences, IFTM University, Moradabad, for their kind support and providing all the necessary facilities and encouragement for successful completion of this work.

\section{CONFLICTS OF INTEREST}

The authors report no conflicts of interest.

\section{AUTHORS' CONTRIBUTION}

Neelam Jain: Concept, design, collection of the data, laboratory investigations, and drafting the final report. Anurag Verma: Supervised the findings of this work and discussed the results and contributed to the final manuscript.

\section{AUTHORS' FUNDING}

The authors received no specific funding for this work.

\section{REFERENCES}

1. Aulton ME. Aulton's Pharmaceutics: The Design and Manufacture of Medicines. $3^{\text {rd }}$ ed. London, United Kingdom: Churchill livingstone; 2007. 
2. Rosin A. Pilocarpine: A miotic of choice in the treatment of glaucoma has passed 110 years of use. Oftalmologia 1991;35:53-5.

3. Khaw PT, Shah P, Elkington AR. Glaucoma-2: Treatment. BMJ 2004;328:156-8

4. Jain N, Verma A, Jain N. Niosomes encapsulated pilocarpine hydrochloride for ocular controlled delivery. Int J Pharm Bio Sci 2019;9:813-23.

5. Available from: https://www.drugbank.ca/drugs/DB01085.

6. Jain N, Verma A, Jain N. Anti-glaucomatic niosomal gel: A brief review. World J Pharm Pharm Sci 2020;9:529-48.

7. Tomar S, Singhal T. Preformulation studies of niosomal gel of prednisolone and azithromycin for topical drug delivery system. J Innov Pharm Biol Sci 2015;2:312-21.

8. United States Pharmacopeia-National Formulary. The Official Compendia of Standards. United States: United States Pharmacopeial Commission; 2007.

9. Jayanthi B, Madhusudhan S. Preformulation characterisation, designing and formulation of aceclofenac loaded microparticles. Int J Drug Dev Res 2012;4:186-96.
10. Lachman L, Lieberman HA, Kanig JL. The theory and practice of industrial pharmacy. $3^{\text {rd }}$ ed. Ernakulam: Varghese Publishing House; 1986.

11. Berthod A, Broch SC. Determination of liquid-liquid partition coefficients by separation methods. J Chromatogr A 2004;1037:3-14.

12. Meylan WM, Howard PH. Atom/fragment contribution method for estimating octanol-water partition coefficients. J Pharm Sci 1995;84:83-92.

13. Jain N, Banik A, Gupta A. Novel interpenetrating polymer network microspheres of lepidium sativum and poly(vinyl alcohol) for the controlled release of simvastatin. Int J Pharm Pharm Sci 2013;5:125-30.

14. Jain N, Kumar H, Rajpoot AK, Verma HC. Novel interpenetrating polymer network mucoadhesive microspheres of locust bean gum and poly(vinyl alcohol) for the delivery of famotidine. MIT Int J Pharm Sci 2015;1:27-36.

15. Jain N, Verma A, Jain N. In vitro evaluation of niosomal gel containing pilocarpine hydrochloride for ocular delivery. Lat Am J Pharm 2020;39:431-8

16. Schoenwald RD, Huang HS. Corneal penetration behavior of beta blocking agents I: Physichochemical factors. J Pharm Sci 1983;72:1266-72. 